\title{
THE DIALECTICS OF ENGLISH DOMINANCE
}

\author{
ODROWAZŻ-COATES, ANNA. 2019. SOCIO-EDUCATIONAL FACTORS \\ AND SOFT POWER OF LANGUAGE. THE DELUGE OF ENGLISH IN PO- \\ LAND AND PORTUGAL. LANHAM: LEXINGTON BOOKS (ROWMAN \\ \& LITTLEFIELD), ISBN: 978-1-4985-7633-8, 188 PP. (HARDBACK)
}

\author{
LILIA D. MONZO ${ }^{1}$ \\ ${ }^{1}$ Chapman University, Attallah College of Educational Studies, Reeves Hall 136333 N Glassell St Or- \\ ange, CA 92866, USA. ORCID: 0000-0002-8988-3940, Email: monzo@chapman.edu
}

The Hegemony of English across the world cannot be overstated (Macedo, Dendrinos \& Gounari 2016). More and more nations are encouraging, if not mandating through compulsory education requirements, that their citizens learn English (Xue \& Zuo 2013). This demand for English is rising even among countries who have few native speakers of English. Importantly, making any language learning a national project carries a critical message about that language and its power. Robert Philipson (2011) points out that this growing demand and compulsory establishment of English (through schooling) can be nothing less than linguistic imperialism, with the World Bank re-introducing the historical colonial order. Nations are clamoring to learn English as quickly as possible in the hopes that doing so will boost their competitive edge on the global market (McCormick 2013). Indeed, there is evidence that English proficiency elevates the status and power of specific nations and provides individuals greater access to jobs and resources, but as Anna Odrowaz-Coates shows, in the case of Portugal and Poland, this will not happen without a significant cost to the national identity and to the identities of the people and their families and communities.

What Odrowaz-Coates argues and evidences with empirical data is that language is not a neutral system of communication but rather one that carries with it particular sociohistorical, economic, and political agendas that undoubtedly impact people's 
lives in profound material and ideological ways. Odrowaz-Coates' analysis of "soft power" recognizes the subtle but insidious ways in which English (and its worldviews) becomes normalized as a status factor that not only creates further material inequities in society, but that also undermines the primary languages and cultures of its peoples.

This is a stunningly brilliant book that challenges the global hegemony of English and US imperialism through the very voices of the people most affected. This alone, makes it a superb read. However, with both philosophical and theoretical rigor as well as robust empirical research, Anna Odrowaz-Coates brilliantly pushes our thinking further to develop a reflexive, feminist praxis of English foreign language policy - one that recognizes the dialectical relationship between English learning and opportunity. While many of us challenge the global dominance of English and its imperialist agenda, there is no doubt that for many of us - English proficiency - has facilitated our roles within the academy. Here Odrowaz-Coates reminds us that while we work toward the long-term goal of justice and equity, where all languages and peoples are equally valued, people today need access to resources and to become more empowered within the contexts of their existing world - and this, like it or not, means learning English.

The book begins with a strong philosophical and theoretical foundation. OdrowazCoates draws on "soft power" and "positioning theory" as well as the specificity of institutional ethnography to hone in on the examination of language, which has not been previously developed and offers important insights that differentiate between obvious forms of power in discourse in ways that explain the subtleness by which discourses are internalized among those who are uncritically exposed to English. This interdisciplinary theoretical frame is one of the strongest features of this work, drawing from Foucault, Bourdieu, and decolonial and postcolonial theories to make a cogent argument about the ways in which learning English in Poland and Portugal simultaneously supports empowerment and imperialism. This is a very significant contribution, given that rarely do these fields come together even when they address similar problems. Furthermore, the application of these theories to language and discourse is certainly an important and unique contribution.

Until now, few studies have attempted to examine what this national process of English development looks like or how it impacts the people whose languages and traditions may be far removed from those that they are being required to adopt. In the findings chapters, Odrowaz-Coates takes us into the contexts of Portugal and Poland to help us understand, through real life examples, how learning English for some working people can have both important material improvements while at the same time challenging their ways of life and their relations to nation, family, and self.

The voices of participants are a central feature of why this work is so unique. Rarely do we find books of this theoretical rigor that also bring the concrete reality of people's lives into focus. Here, we are privy to the values and beliefs of people from Poland and Portugal and to the gendered realities and expectations that come with language shifts. With stunning precision, the author uses the participants' words to convey some of the most important issues related to learning and not learning English.

With a rigorous mixed methods approach couched within the umbrella of "institu- 
tional ethnography" and the author's humbling reflexivity, we can feel secure in the trustworthiness of the study. The manuscript also has a highly cogent and fluid style, carefully building its arguments and supporting these with the empirical data collected. As the reader, I was unable to put the manuscript down, challenged to discover the way the author was connecting "soft power" with institutional discourse, captivated by the very honest and insightful comments by participants, and lured to continue reading to find the brilliant analysis that the author repeatedly provides.

Odrowaz-Coates begins with an introductory chapter that gives the reader a broad view of the book and piques our interest by dangling new ideas and meshing theoretical constructs. The next chapter titled, "Language positioning in Poland and in Portugal" focuses in on the history of language contact in Poland and Portugal, and demonstrates that language is not a mere tool of communication but a tool that can and often has been used to control and dominate over a citizenry. Coates traces how language policy shifts in accordance with who has governmental control and the political agendas they set. This chapter is filled with historical detail of the complex histories of Poland and Portugal, where language has been shaped by religion, colonization, migration, economic shifts, and even marriage, not only within nations but outside of it. The chapter documents both the endurance and flexibility of language as it comes into contact with other languages and the power that certain nations and their languages hold. It also documents how schools become spaces that support government entities to engage in their language wars. This is a fascinating and engrossing chapter.

The next few sections revolve around theory and develop a careful explanation of the theories that guide this work, connecting theories of soft power with positioning theory and discussing the ways that language discourses both reflect and create power and particular social positionings for speakers, communities, and nations. Drawing on the likes of Bourdieu, Boudon, Foucalt, and Fairclough, Odrowaz-Coates guides us to understand how these various works come together to explain that phenomena of language and power in the context of globalization. This chapter is a necessary read to understand what comes later - the analysis interwoven with the empirical data is very effective and illuminating.

The voices of the people who speak to us of their trials with learning English, with finding jobs, with figuring out who they are in the context of a growing English dominance and changing cultures and values is what follows. These are the most captivating sections, where people come to life and our critical challenge to the dominance of English is quickly confronted as we begin to hear and see the people that are in need and for whom English may be a safety net or hold the possibility of mobility. But equally evident in the words spoken is the loss of culture, world views, and even ways of being through increasing contact with English. The mythical narratives of opportunities in America (and therefore in English) begin to show their teeth as they eat away at local values in the hope of something better for themselves and their children. Yet, don't be fooled into thinking that the people are easily swayed, there is consciousness regarding the power of English and its manipulation. The people of Portugal and Poland are shown insightful, passionate, and agentic. For women, the "choice" of learn- 
ing English may prove beneficial as they negotiate gender relations within the family. Unlike too many other critical projects, Odrowaz-Coates conveys the ethical imperative to change the world by both challenging but also participating in the existing power structures. It recognizes the need to "play the game" in order to change it. Above all, this work demonstrates that language "choices" are not necessarily choices but institutionally derived programs of both inclusion and exclusion.

This is a crucially important and timely project given our globalized world and the significant influence that English and US imperialism are having on the world. The book does a great job in making the urgency of this clear by showing the growth of English dominance around the world and using Poland and Portugal as unique case studies, that nonetheless serve as examples of growing trends across the world. In this sense, this work is crucially important for scholars and practitioners in the fields of education, cultural studies, postcolonial studies, immigration studies, sociolinguistics and language studies, sociology and political science. The work is essential reading for public officials, politicians, and language policy makers. Critical scholars across these fields are certain to find this work immensely provocative. It is a must read for school administrators, teachers, community members, and families in Poland and Portugal, but also across the world where students are being encouraged, pushed, or even mandated to learn English.

\section{REFERENCES}

Macedo, Donaldo, Bessie Dendrinos \& Panatoya Gounari. 2016. The Hegemony of English. New York: Routledge.

McCormick, Christopher. 2013. "Countries with better English have better economies." Harvard Business Review, Nov. 15. Retrieved December 10, 2019 (https:// hbr.org/2013/11/countries-with-better-english-have-better-economies).

Phillipson, Robert. 2011. "English: from British empire to corporate empire." Sociolinguistic Studies 5(3): 441-464.

Xue, Jiao \& Wenjing Zuo. 2013. "English dominance and its influence on international communication.” Theory and Practice in Language Studies 3(12): 2262-2266.

FUNDING: This research received no external funding.

CONFLICTS OF INTEREST: The author declares no conflict of interest.

\section{BIOGRAPHICAL NOTE}

Lilia D. Monzo is an associate professor in the Attallah College of Educational Studies at Chapman University. She received the Ph.D. in Education from the University of Southern California. Her recent research draw on revolutionary critical pedagogy to interrogate and confront the educational and so- 
cio-political contexts impacting Latino communities in the United States and América Latina.

OPEN ACCESS: This article is distributed under the terms of the Creative Commons Attribution Non-commercial License (CC BY-NC 4.0) which permits any noncommercial use, and reproduction in any medium, provided the original author(s) and source are credited.

ARTICLE HISTORY: Received 2019-12-21 / Accepted 2020-02-23 
